ARTICLE

DOI: $10.1057 / \mathrm{s} 41599-017-0041-0$

\title{
The future of the impact agenda depends on the revaluation of academic freedom
}

\author{
J. Britt Holbrook (D) ${ }^{1}$
}

\begin{abstract}
Opponents of the impact agenda often base their arguments on the claim that requiring scholarly research to demonstrate broader societal impacts conflicts with academic freedom. This paper argues that this claim entails a narrow interpretation of academic freedom as freedom from interference. A richer interpretation is proposed of academic freedom as freedom to pursue research that may have broader impacts. Adopting a positive view of academic freedom will require disciplines to adjust their standards of academic rigor and universities to amend their criteria for promotion and tenure. It will also provide the foundation for an academic response to the rise of neopopulism.
\end{abstract}

\footnotetext{
${ }^{1}$ New Jersey Institute of Technology, Newark, NJ, USA. Correspondence and requests for materials should be addressed to J.B.H. (email: holbrook@njit.edu)
} 


\section{Introduction}

- he notion of an "impact agenda" refers to policy makers' attempts to impose accountability on academics for the public funding of research. The impact agenda thus requires academics to address not only the intrinsic value of their research in advancing knowledge-its academic merit-but also the value their research has to society-its broader impacts. Beginning in the 1990s, the impact agenda took on various forms, depending on the particular context (see, for example, Bornmann, 2013; Derrick and Samuel, 2017; Donovan, 2008; Holbrook, 2010; Holbrook and Frodeman, 2011; Langfeldt and Scordato, 2015, and Rip, 2000). But whatever the differences in various approaches to broader impacts, the impact agenda was rooted in neoliberalism, the dominant policy orientation in the United States and Europe.

This essay attempts to think critically about the future of the impact agenda in the context of the recent political shift away from neoliberalism and toward neopopulism. The author employs conceptual analysis rather than relying on empirical data. The point is neither to provide evidence that the author's views are correct nor to predict the future-either of politics or of impact. Instead, this essay aims to provoke a conversation both among academics and between academics and members of society about the value of academic research. The author may sometimes exaggerate or oversimplify in service to that end.

The title of this paper suggests that academics have, and should seize, the opportunity to reorient the impact agenda; it is not a cry to save it. Reducing the value of universities to their economic returns on investment-a succinct way of describing the neoliberal policy for higher education-was always a mistake. The other option, championed by most academics, especially at the advent of the impact agenda, that scholarly impact captures the value of research, also missed the mark. Where policy makers valued research only for its extrinsic effects, academics valued research only for its intrinsic worth. Although some academics eventually came to embrace the impact agenda, cynics charged that defining better research simply as research with more societal impact was the result of self-serving motives (Allen, 2014).

The discussion surrounding impact involved essentially three types ${ }^{1}$ of characters:

1. Policymakers, who wanted evidence of impact to demonstrate return on investment; ${ }^{2}$

2. Academic opponents of impact, ${ }^{3}$ who viewed the impact agenda as a violation of academic freedom; and

3. Academic champions of impact, ${ }^{4}$ who saw impact as another opportunity to demonstrate their value.

Policymakers found themselves at odds with the opponents of impact and largely in agreement with its academic champions. Academic opponents of impact saw their impact-champion colleagues as self-serving sellouts (Braben et al., 2009; and cf. Chubb and Watermeyer, 2016). Academic champions of impact saw their impact-opposed colleagues as ostriches burying their heads in the sand and held that it would be better to engage policy makers to expand impact beyond market concerns (Cf. Frodeman, 2017). Things are different now.

Now, the terms of the debate have changed, at least in the United Kingdom (UK) and the United States (US). Neoliberalism has floundered politically, and neopopulism ${ }^{5}$ has yet to propose clear new policies for higher education. The impact agenda is not yet dead, but it is disoriented. We are left with neoliberal policies bereft of their ideological grounding. Although we do not yet know for certain what policies neopopulism may propose for education, there is a growing sense of fear among academics. Witnessing the attacks on mainstream media, the dismissal of experts, and the all-around assault on truth, academics are beginning to realize that universities-where experts pursue truth - present likely targets. But academics have yet to come to grips with the new terms of the debate.

If neoliberalism required academics to make their case to the government in terms of impact requirements, neopopulism demands that academics make their case to the people.

This essay reviews the old and attempts to establish some new terms of the discussion revolving around impact. I begin $(\$ 1)$ by situating the impact agenda within neoliberal policy for science. I then $(\$ 2)$ explore underlying philosophical beliefs about academic freedom and their relation to two means of evaluation of academic performance: promotion and tenure criteria ${ }^{6}(\$ 3)$ and peer review (\$4). I then briefly trace the fall of neoliberalism $(\$ 5)$ and the rise of neopopulism, including its possible implications for higher education policy (\$6). Finally, (\$7) I suggest a way forward, with the academic community leading the way.

\section{Neoliberalism and the old terms of the debate}

Neoliberalism was the dominant non-partisan ideology, especially of Western democracies, since the 1980s. Pinochet's Chile was the testing ground, as the so-called "Chicago Boys" instituted what were then termed free-market reforms (as advocated by the likes of Milton Friedman, the University of Chicago economist) as the new economic policy. Seen against the backdrop of Chile's previous economic policy of import substitution industrialization, which had focused on the development of an internal market for Chile through state-directed central planning and protectionist tariffs, neoliberalism was a free-market reform. Neoliberalism focused on monetarism to maintain price stability, supply-side economics, minimizing the role of the state (especially in terms of welfare provisions and redistribution of wealth), and an emphasis on global markets. However, neoliberalism is not simply a laissezfaire approach to economic policy; it also foists an economic reading on society as a whole. Under neoliberalism, then, whereas the role of the state decreased (less welfare, less regulation), the role of the government actually increased, specifically by requiring the government to set up the rest of society as if it were the market.

Under a neoliberal ideology, the government not only sets policies to minimize the state and maximize the global market, but also sets policies to provide "market" incentives for individuals to perform in the way that the government would like. As Foucault (2008) suggests:

Government must not form a counterpoint or a screen, as it were, between society and economic processes. It has to intervene on society as such, in its fabric and depth. Basically, it has to intervene on society so that competitive mechanisms can play a regulatory role at every moment and every point in society and by intervening in this way its objective will become possible, that is to say, a general regulation of society by the market. (145)

This sort of government intervention on society to install competitive regulatory mechanisms is one aspect of what Foucault calls neoliberal governmentality. Another aspect is (leveraging) the freedom individuals have to respond to the power exerted on them by those competitive mechanisms.

With regard to higher education policy, the most obvious of such mechanisms is the introduction of societal impacts criteria as part of public funding decisions. Scientists and engineers have been asked by the US National Science Foundation (NSF) since FY1998 to address not only the Intellectual Merit, but also the Broader Impacts of proposed research (Holbrook, 2012). In the UK, both aspects of the dual funding system, competitive grants 
to researchers managed by the Research Councils UK and allocations of funds to higher education institutions by the Higher Education Funding Council of England by means of the Research Excellence Framework, include considerations of societal impact. The European Commission also employs impact criteria as part of the Horizon 2020 programme of the European Union (EU) (Holbrook and Frodeman, 2011).

Neoliberal policy makers had installed societal impact as the competitive regulatory mechanism for academic research, thereby creating the impact agenda. Although most academics (the opponents of impact) responded with resistance (Braben et al., 2009), eventually some academics (the champions of impact) responded by attempting to operate within the impact agenda and turn it to their advantage (Academics Anonymous, 2016). Of course, none of these positions is univocal (Cf. Chubb, 2017). It would be especially misleading to accept the cynical reading of the champions of impact promulgated by some opponents of impact at face value. A more charitable reading would suggest that the champions of impact included those who wanted to resist the impact agenda from within, redefining impact on their own-not exclusively economic-terms in order to benefit academics as a whole (Holbrook et al., 2013). However, the difference between the academic opponents and champions of impact was not merely a disagreement about strategies. Different underlying philosophies, especially surrounding the idea of academic freedom, were also at work.

\section{Two concepts of academic freedom ${ }^{7}$}

Isaiah Berlin (1958) distinguished between two concepts of liberty: negative liberty, which can be summarized as freedom from constraint, and positive liberty, which can be summarized as freedom to pursue a self-determined course of action. Berlin argued in favor of negative liberty, since the great danger of positive liberty was that the self-determination required for full autonomy under positive liberty could potentially be co-opted by others. In other words, operating under a conception of positive liberty might open us up to domination by others, who could tell us we were not really free unless we operated according to their positive notion of liberty. By adopting a negative view of liberty, more akin to the position of classical liberalism, we could safeguard ourselves against the possibility of domination. Although Berlin's account was specifically about liberty in a political context, these two concepts of liberty are also relevant to academic freedom and to the different reactions of academics to the impact agenda.

A negative view of academic freedom suggests that academics should be, as far as possible, free from constraint. Many, if not all, opponents of impact appeal, at least implicitly, to such a negative view of academic freedom to suggest that impact requirements represent just such a constraint, thus violating academic freedom. A positive view of academic freedom suggests that academics should be able to decide for themselves the course of their research and teaching. Many academic champions of impact suggest that impact requirements, as long as they are vague enough, allow enough room for academics to determine the course of their own work, thus remaining consistent with academic freedom. In other words, the idea that new knowledge ought to be considered not only intrinsically valuable, but also to have societal impact, is consonant with a positive view of academic freedom, as long as the academic is free to decide for herself how that knowledge and impact are to be pursued.

One problem with the negative interpretation of academic freedom is that it seems not to provide enough accountability for academics. Indeed, taken to the extreme, the negative view of academic freedom requires no accountability. Most adherents of the negative view of academic freedom suggest, however, that accountability to one's profession or disciplinary peers is sufficient (see $\$ 4$, below). A problem with the positive interpretation of academic freedom is that it might be co-opted by others, for instance, neoliberal policy makers who might allow academics to choose 'for themselves' how to achieve societal impact, narrowly defined in market terms (see $\$ 5$, below).

A related difference between opponents and champions of impact is their views on the value of research. Impact opponents tend to suggest that research has intrinsic value and should be pursued only for its own sake, while impact champions favor the idea that research pursued for the sake of some other goal (such as its potential broader societal impacts) ought also to be considered valuable (Cf. Chubb, 2017).

Stanley Fish (2014), who supports what he calls an "internal justification" for academic freedom, argues forcefully against any sort of external, instrumental grounding:

The main objection to the "academic freedom is necessary for democracy" thesis is not that it is hubristically elitist (although surely it is), but that it is one more way of locating the value of academic work in the service it performs for another enterprise. "It's good for democracy" is just another, albeit more appealing, version of "it's good for the state's bottom line" or "it's good for the fashioning of character." The implication is that if academic work and the freedom to do it properly are to be justified, the measure of justification will come from elsewhere. (p 48)

Whether the 'external' justification is democracy, the state, or Bildung, Fish rejects them in favor what he calls the "It's just a job" approach to academic freedom:

An internal justification for academic freedom is all the "It's just a job" school can offer-this is the job and these are the conditions we require to do it properly. But the minimalism of that justification (not really a justification at all) is purchased at the price of not having anything to say when a legislator or a businessman or a taxpayer asks "Yes, I see why that's good for you, but why is it good for me?" The "It's just a job" school's inability -indeed its unwillingness -to answer that question is at once its greatest weakness and its greatest strength. It is its greatest weakness because it gives up on the public relations task before it is even begun; it is its greatest strength because, in refusing the challenge of public/political justification, it reaffirms the independent value of what academics do, and provides a secure, because wholly internal, justification of allowing them to do it freely. ( $\mathrm{p}$ 49)

Academic freedom, for Fish, is the ability to pursue inquiry limited only by the professional norms of academia. Research has intrinsic value, and this is what justifies academics' freedom to engage in it. For many of the academic champions of impact, the sort of internalist account offered by Fish had become a stultifying focus on scholarship for its own sake. The contrast between the negative and positive conceptions of academic freedom can be seen in even starker relief if we look at criteria for tenure and promotion. $^{8}$

\section{Tenure-tracking from means to end}

According to the American Association of University Professors (AAUP) 1940 Statement of Principles on Academic Freedom and Tenure, tenure is supposed to be a means to secure the end of academic freedom, not the end of an academic's career:

Tenure is a means to certain ends; specifically: (1) freedom of teaching and research and of extramural activities, and 
(2) a sufficient degree of economic security to make the profession attractive to men and women of ability. Freedom and economic security, hence, tenure, are indispensable to the success of an institution in fulfilling its obligations to its students and to society. (p 3)

As competition for tenured academic jobs has increased, however, tenure has increasingly been identified with the end of economic security. Those lucky enough to secure a tenure-track position these days are typically advised to 'do what it takes' to be granted tenure. "What it takes" is to "play the game", the rules of which are laid out in terms of a set of criteria for tenure, including especially publishing a certain amount of scholarship (a number of articles or a book) in certain venues ("high impact" journals or top academic presses). The first 7 years or so of an academic's career are thus spent with one aim in mind: securing tenure. Moreover, academics are trained to adhere strictly to disciplinary standards of what counts in order to achieve the end of tenure. The idea that tenure is a means to secure freedom of teaching and research has dropped out, replaced by the idea that tenure equals economic security, provided one follows the rules of the game.

Once tenure has been granted, scholars do view themselves as free-free from the overwhelming pressure to publish or perish. Provided that minimal standards are met, the tenured scholar is generally safe to go about her or his business of teaching and research without too many external constraints. Academic freedom has been effectively reduced to the idea of negative liberty.

Another sign that we academics have lost track of the meaning of tenure is that scholarship has come to be seen as the means to achieve tenure, rather than as one end of an academic's career. Insofar as academics tend to view tenure as the end and scholarship as the chief means to that end, academics also tend to undervalue other positive aspects of academic freedom. Today, teaching is at most an afterthought, whereas the AAUP's, 1940 statement refers to the rights of "teachers" as being entitled to freedom in research, publication, and in the classroom. The 1940 statement also acknowledges the rights of academics as "citizens," as well as teachers. Today, in the US at least, engaging the community outside of academic circles is largely discouraged, if not punished, in terms of promotion and tenure. ${ }^{9}$

Rather than aiming to do good scholarly work, be a good teacher, and make a positive impact on the world, academics aim to achieve tenure. This means that they are required to teach, get grants, and, above all, publish a certain amount of scholarship. As a result, today's academics have trained themselves to care not what they are free to do, but only the extent to which they are free from being required to do things. How little can I teach? How much do I have to publish? Do I really need to achieve impact?! That scholars tend to undervalue the positive aspects of academic freedom has important ramifications for the course of scholarship (not to mention teaching). Nowhere is this fact more evident than in the process of peer review.

\section{Peer review-from state control to paradigmitis}

Biagioli (2002) argues that peer review was originally used as a complement to state censorship-foreign products were censored, while those produced within the state under the auspices of national academies were subject to "internal", that is, intra-state, peer review. The notion of an internal peer-and a growing recognition of areas of expertise-gradually shifted the locus of power to academic disciplines. Today, due especially to the scientific community, peer review is considered a guarantor of epistemic warrant, as well as viewed as another means of securing academic freedom. However, the sort of academic freedom peer review secures is negative-peer review erects a barrier against outside, non-academic, interference (Holbrook, 2016). What is lacking is any sense that peer review could also be used to expand our positive freedom. Instead of what Fuller (1999) describes as the "right to be wrong", academics assert their expertise: the "right to be right-or at least to avoid being wrong-in our own little world". Academics seek assurance from their peers that what they say is right, or at least not wrong, rather than insurance from peer review to take intellectual and academic risks.

Rather than encouraging academics to take risks, peer review enforces standards - of rigor, of method, of subject matter, and generally of what counts as good research within a discipline. When a piece of research is subject to peer review, it usually means that disciplinary standards will determine whether it passes muster to be published (in the case of a manuscript submitted for publication) or to be funded (in the case of a grant proposal). Decisions regarding promotion and tenure involve a larger body of work than a single manuscript or proposal; but this body of work is also usually subject first and foremost to disciplinary peer review (by peers within the candidate's department and external referees, who are typically scholars of high standing within the same discipline).

Tenure decisions also involve review by members of the faculty from disciplines other than that of the person up for tenure review. These tenure review committees tend to rely heavily on the reports of the disciplinary peers from within the department and letters from external disciplinary reviewers. The largest factor in their decisions, however, is the candidate's record of peer reviewed publications (National Research Council, 2012; Harley, 2013). Such publications ideally appear in the top journals within the researcher's field of expertise. In other words, nondisciplinary "peers" place their trust in the judgment of disciplinary peers.

Peer review, then, whether of manuscripts or grant proposals or bodies of work put forth to make a case for tenure, is typically dependent on disciplinary norms. Its use as the preferred method for the assessment of the quality of scholarship (for publication, for grants, for tenure, and so on) may be seen as symptomatic of what Fuller (2000) has termed "paradigmitis"-the tendency to think that if a method works in one situation, it must work in all others. Peer review also tends to be conservative, encouraging adherence to "normal" rather than "potentially transformative" research (Frodeman and Holbrook, 2012). Peer review thus serves to make sure academics play it safe, rather than as a safety net to catch them when they fall. Part of playing it safe is also the appeal to peer review to shield academia as a whole from societal influence and control.

The proclivity most academics share for peer review all but guaranteed that it would be the tool of choice for assessing impact, despite the concerns of academic experts in the field of research evaluation (Martin, 2011). There are, then, instances in which academics identify as such, at least in their trust in the reliability of the method of peer review, without deferring to the experts in a more traditional Kuhnian (discipline-sized) paradigm. Indeed, whenever society threatens to encroach on academia, peer review and the overarching expertise it relies on are the typical defenses. Even if academics are really experts in rather small areas of specialization (subdisciplines), their attitude toward peer review evinces their faith in expertise writ large (academia).

Viewed from a neoliberal perspective, impact was a way of capitalizing on academics' faith in their own expertise. Even if academics resented and resisted impact, their ultimate judgment was that they themselves were the best qualified to assess it. Neoliberalism had quite cleverly installed just the right market incentive to begin to turn academics toward societal-rather than merely professional-accountability. 


\section{The end of neoliberalism}

Although few recognized it at the time, the passage of the American Recovery and Reinvestment Act of 2009 signaled a shift away from neoliberalism and a return to a more Keynesian economic approach (Obamacare is also a sign of this shift). Strains on neoliberal science policies were also evident during the Obama administration. The NSF's Merit Review Process underwent a reexamination by the National Science Board at the behest of Congress (mandated by the America COMPETES Act of 2007, Public Law 110-69). America COMPETES contained a list of "national goals" that the NSF's Broader Impacts Criterion might be used to meet. The National Science Board, the governing body of NSF, considered adding the list of goals to the Merit Review Process itself, providing researchers seeking grants with a sort of checklist of possible impacts (Holbrook and Frodeman, 2011).

Arguably, the push to add the list of goals is itself consistent with a Keynesian approach, ensuring a larger role for government in directing the course of research (albeit under the guise of accountability), rather than setting up incentives and allowing researchers to choose how they would respond, as under neoliberalism. With its 2011 Review and Revisions of the NSF Merit Review Process (NSB/MR-11-22, 2011), though, the National Science Board ultimately opted not to include the list, on the grounds that it would be too directive and interfere with the freedom of researchers (Holbrook, 2012). However, when he signed the American Innovation and Competitiveness Act (Public Law 114-329)—which reintroduces the list of national goalsinto law just prior to leaving office, Obama officially laid neoliberal science policy to rest in the US.

\section{The rise of neopopulism and the plight of experts}

When, in June 2016, approaching the Brexit Referendum in the UK, pro-Brexit campaigner Michael Gove suggested that the people had "had enough of experts"- even though it was obvious to anyone who watched the interview that this simplistic thought was not the point, much less the correct quote-it struck at least two nerves. First, academics, who view themselves as experts, of course, reacted with derision. Second, many of the people who voted for Brexit indicated that Gove-or fake Gove-may have had a point.

When Trump came to power in the US, the term "fake news" became "fake news media", and Kellyanne Conway unleashed the notion of "alternative facts" on the world. Before the end of Trump's first 100 days in office, the experts around the world, along with their fans, took to the streets in the March for Science (which, it turns out, was over 600 marches around the world). "No science, no beer," explained one sign to the non-experts. The trouble, of course, is that what this sign and many other signs carried by the marchers for science claimed is actually false. Beer, probably the oldest alcoholic beverage, was discovered thousands of years before Thales, the world's first philosopher (also claimed by scientists as the world's first scientist), proclaimed, "All is water." It did not, in fact, take science to produce beer. Alternative facts, indeed.

Experts seem to hear the notion of alternative facts as an attack on facts, truths to which they themselves have unique access, but which they graciously share with society (or at least publish in peer reviewed journals, as if that were sufficient). But far from reacting with gratitude, people who are not experts in any particular area may begin to question "the experts" whose advice so often seems to result in policies that hurt, rather than help, them. Suggesting that those who do not share the experts' views are delusional, willfully ignorant, or otherwise defective is no way to win friends and influence people. Implying that the people ought to be thankful for the gifts science provides (yay, beer!) completely misses the point. Even worse, it comes off as the experts' "let them eat cake" moment.

Miller (2017) suggests that the plight of experts is having mistaken their enemy. Experts hear about "alternative facts" and rush to defend "the facts", which are, of course, produced by science. Yet Miller argues that questioning expertise is not part of a "War on Science". Instead, "For conservatives, the enemy is not science itself but the further expansion of powerful, centralized, science-informed government" (Miller, 2017). According to Miller, attacks on expertise are simply a tactic in the larger ongoing Republican war on big government.

If Miller is correct, then it seems that I may have mistaken Trump, a typical Republican, for a sign of the rise of neopopulism in the US. It is certainly possible to see the apparent rise of Jared Kushner and Ivanka Trump, with the corresponding waning of Steve Bannon's influence, as signs that Trump will, in fact, move in that direction. But what if I have not made a mistake? Miller's analysis brilliantly explains why Republicans in the US have embraced Trump-as a means to reduce the size of the federal government-but does the fact that Republicans have embraced him signify that Trump himself is a typical Republican? And how does Miller's analysis of the Republican war on big government in the US square with events in Europe?

Miller's story about the role of science in justifying the expansion of the US federal government (not to mention supporting the expansion of US businesses) strikes me as largely correct. However, I suggest that we extend Miller's point-that science has been used to expand the power of the governmentto cover the rest of the world. Although it is certainly the case that Reagan's rhetoric supported the idea of smaller government, it is relatively uncontroversial to note that Reagan was the major political instigator of neoliberalism in the US (much like Margaret Thatcher in the UK). Seen in this light, it is not that Reagan's gutting of the Environmental Protection Agency was a conservative (classical liberal) attack on big government; rather it was a neoliberal move to shift power away from the state, to shift everything from state control to market mechanisms.

Under neoliberalism, the science was economics. The impact agenda was an effort to make the other sciences operate according to-or at least in service of-economic principles. If the statist approach (consonant with Keynesian economics) used science as a tool to help the state control more and more of society (regulation), the neoliberal approach used science to help retool society to run according to market incentives (governmentality; or less state, more global government). Once the remaining sciences started to operate with market mechanisms, they also served the neoliberal agenda (often by providing measurements to determine whether others were meeting their market goals).

Neoliberalism is one with classical liberalism in rooting its philosophy in individual liberty. However, where classical liberalism interprets individual liberty as freedom from constraint (negative liberty), neoliberalism interprets individual liberty as freedom to pursue market incentives (positive liberty). Neoliberalism also has a global focus, rather than a merely national one. Agencies such as the World Bank and the United Nations increased in influence under neoliberalism. International free trade was all the rage. The EU expanded, as well. Today, the EU remains the single most powerful political entity still operating according to neoliberalism; the impact agenda as we have known it will remain alive in the EU as long as it continues to do so.

Things are different in the US and the UK, however. "Make America Great Again" (MAGA) and Brexit are one in the rejection of neoliberalism. Neopopulism will take different forms in different countries, however. MAGA includes a hostility to globalism, especially in terms of global free trade. MAGA includes a hostility to immigrants. MAGA includes a focus on economic 
nationalism, a very non-Keynesian statism. MAGA certainly seems to be about decreasing the size of the federal government, although not necessarily its power-Trump refuses to nominate people to fill hundreds of jobs in the administration that require Senate approval, in the name of keeping the government small; yet he attacks the judiciary and attempts to coopt sanctuary cities in his war on immigrants. The point is to concentrate more power in fewer hands.

Miller (2017) reads Bannon's claim that the Trump administration aims at the "deconstruction of the administrative state" as typical Republican conservatism's resistance to big government. This reading fails to account for the fact that Republican presidents since Reagan, as well as Democrats up until Obama (including presidential nominee Hillary Clinton) were all neoliberals. I suggest that the point of Bannon's remark was not to say that Trump is a typical Republican; instead, Bannon was signaling a shift away from neoliberalism:

You know, I've said that there's a new political order that's being formed out of this. And it's still being formed. But if you look at the wide degree of opinions in this roomwhether you're a populist; whether you're a limited government conservative; whether you're libertarian; whether you're an economic nationalist-we have wide and sometimes divergent opinions.

But I think we-the center core of what we believe, that we're a nation with an economy, not an economy just in some global marketplace with open borders, but we are a nation with a culture and $a$-and a reason for being.

And I think that is what unites us and I think that is what is going to unite this movement going forward. (Blake, 2017, emphasis added)

The "center core" of Trump's version of neopopulism is economic nationalism, which is to say one approach to rejecting neoliberalism. Theresa May will have her own center core, as will other neopopulists in other countries (including, perhaps, some coming from the left rather than the right).

\section{The new terms of the debate}

Supposing that the rise of neopopulism is not in fact simply the triumph of classical liberalism (traditional small-government conservatism in the US, say), but rather the movement to "repeal and replace" neoliberalism, what does that have to do with the future of the impact agenda and academic freedom? The first response should be to admit that we do not yet know the answer to that question. To echo some of Bannon's sentiments, neopopulism is still being formed. In the US, it is by no means clear that the right wing version supported by Trump will ultimately win out over left wing versions of neopopulism put forward by Bernie Sanders or Elizabeth Warren. France recently face a choice between Le Pen's far-right neopopulism and the continuation of neoliberalism under Macron. With Macron's win, the EU still has life. As long as the EU survives, the impact agenda will carry on, business as usual, there.

The renegotiation of the impact agenda has already begun in the US and the UK. The government in the latter decided to keep the TEF (a neoliberal policy), albeit now subject to an independent review; and universities are being used as a tool to limit immigration. In the US, on the other hand, the government's anti-immigration stance is negatively affecting applications from international students. The new government in the UK has increased funding for science, while Trump's first budget proposal, which would, among other things, have reduced funding for the National Institutes of Health (NIH) by $18 \%$ was essentially ignored by Congress, which actually added $\$ 2$ billion to the NIH budget (Science News Staff, 2017). In other words, we have no idea what to expect.

Rather than waiting to see what sort of deal the Trump administration proposes for us, as people who think for a living, we academics ought to be able to figure some things out, make some educated guesses, and stake out our negotiating position. I have argued here that the rise of neopopulism is a real phenomenon that deserves our attention. I have also suggested that marching for science (or facts or truth) is not the way to connect with anyone who feels that neoliberalism left them behind. So, how should we proceed?

Although it is clear that many people assume that an undergraduate university degree is necessary for obtaining a goodpaying job, it is also clear that "return on investment" arguments by universities to prospective students ring hollow in the face of the growing student debt crisis (Cf. Newfield, 2017). Should we, as Bernie Sanders and Elizabeth Warren suggest, make college tuition free? Not without first understanding the true cost of attending college, according to Levine (2017). Not unless we actually want to hurt young people, who might do better attending coding bootcamps, according to Adorney (2017). Whom among all these voices-and there are many othersshould we trust?

I'd say always look for the dissenting voice. I think the most important thing is to, when you've got a settled consensus, look at the people who are challenging it. And if you think their arguments are well constructed, then pay close attention; if you think it's just bogus nonsense then fine, but always test every proposition. The idea that things should be taken simply on trust because of someone's position I think is an invitation to intellectual conformity and what we need is a vigorous, debating, dissenting culture. (Chatham House, 2017)

According to Michael Gove, quoted here, the trouble with experts is not, as Miller (2017) suggests, their connection to big government-although one might see so many of them being in favor of remaining in the EU as such-but rather their tendency to foster (or enforce) groupthink. In his first column for the New York Times, Bret Stephens (2017) makes a similar point specifically in regard to the dangers of claiming certainty on today's most settled consensus-climate change science:

Claiming total certainty about the science traduces the spirit of science and creates openings for doubt whenever a climate claim proves wrong. Demanding abrupt and expensive changes in public policy raises fair questions about ideological intentions. Censoriously asserting one's moral superiority and treating skeptics as imbeciles and deplorables wins few converts.

None of this is to deny climate change or the possible severity of its consequences. But ordinary citizens also have a right to be skeptical of an overweening scientism.

Despite his explicit acceptance of climate change here, Romm (2017) went straight to calling Stephens an "extreme climate science denier." Revkin (2017), on the other hand, while noting the "surge of internet rage" sparked by Stephens' column, had a more measured response:

In some ways, the column made clear Stephens had come a distance in his views [away from framing global warming as mass neurosis]. And he flirted with some thoughtfulness about the perils of certainty. But his prime conclusion 
amounted to a defense of forestalling action on climate change while awaiting more certitude.

Here, however, is Stephens' actual conclusion:

Perhaps if there were less certitude about our climate future, more Americans would be interested in having a reasoned conversation about it.

I am not an expert on climate change science (or in any scientific field, for that matter). But perhaps because I am a philosopher (arguably an expert on arguments) and not a climate change scientist, I read Stephens' conclusion as rhetorical advice about how to engage more Americans in a conversation about climate change. Instead of telling people how deplorable they are if they fail to accept what the experts tell them, perhaps we should actually engage with the people in a way that goes beyond simply telling them 'the facts' and demanding they accept them.

In a similar vein, Roger Pielke, Jr. had an interesting response when asked to comment on Trump's 28 March 2017 Executive Order on Promoting Energy Independence and Economic Growth, part of what was characterized by Stover (2017) as part of "Trump's climate blitzkrieg":

Instead of looking at President Trump's executive order on climate as a policy, we might look at it instead as political propaganda. Trump signed the order in front of a group of coal miners. He praised them effusively and solicited a long ovation for them. When is the last time that coal miners have been applauded or even praised by the White House? Many have pointed out correctly that coal jobs are decreasing because of national and global market forces, so it is unlikely that these jobs are coming back. But the point here might not be jobs, but as Aretha Franklin said, R-E-S-P-E-C-T.

Many of those pressing for climate action have embraced the partisanship of the issue, and acted to enhance it. I saw this at play while testifying before the House Science Committee today. Those labeled by the term "climate deniers" might be the original "deplorables." Yale law professor Dan Kahan has concluded that the incessant demand that everyone must believe the same thing on climate science-or they are stupid rubes-actually backfires: "It's a bumper sticker, and it says ' $\mathrm{f}^{\star *} \mathrm{k}$ you' on it."

So long as the climate issue is celebrated as a partisan wedge issue, there will be a huge opening for those who think like Trump to use it as populist propaganda. While partisan food fights are exciting to some, those of us interested in climate action might think about how we got here (hint: it's not all "their" fault)—where "here" is a situation in which climate policies are being rolled back, and few seem to care.

Can those interested in climate action remake the subject into a bipartisan issue respectful of all Americans and their values-regardless of their political party, home state, or education? We'd better, because without broad public support climate policies are going nowhere. We should pay attention to Trump's propaganda, there are lessons for us all there.

I suggest that these lessons apply not only to climate science, but also to science in general, as well as the other forms of knowledge we academics produce. It is vital that we have an impact on society; but in order for that to happen, we need to take a hard look at ourselves.
To take Fish's position-that academic freedom is guaranteed by the intrinsic value of our research and our refusal to engage in "public relations"-is a dangerous path. If we academics suggest that "it's just a job", it is difficult to see how we can make the case that people ought to come learn from us (that is, at universities) when learning to code (which can be done without us) provides a greater return on their investment. A better option would be to embrace the "for the common good" notion of academic freedom, which is what Newfield (2017) urges. However, this approach is susceptible to Fish's charge of elitism-as if we academics could improve society if we taught everyone to think like us.

A better approach still is to teach people who come to university to think for themselves. In order to do that, however, we need to make changes both in our conception of academic freedom and in the university reward system. First, we need to be absolutely clear that academic freedom covers not only academic faculty and staff, but also students. Second, we need to reward teaching as much as we reward scholarship and to reaffirm that the two are inseparable. Third, we need to do away with the notion that research with broader societal impacts is somehow inferior to pure scholarship (Cf. Douglas, 2014). Fourth, and finally, we need to engage with members of the communities in which our universities are situated, and we need to reward that behavior. This sort of engagement should extend well beyond the idea of "public relations" or claims about how beneficial we are to "the public". Engagement is not the one-way transmission of how great we are. Nor is it some sort of "co-production" of knowledge (a remnant of neoliberal ideology). The sort of engagement I am advocating involves a conversation, perhaps leading to potential partnerships and, in general, working together. Realizing such partnerships would require above all encouraging academics and students to think and act in terms of what we are free to do. I say "we" on purpose. I do not want to suggest that academic freedom is exhausted by individuals. Unless we recognize that little impact can be achieved alone, we have little chance of having an impact.

Received: 8 May 2017 Accepted: 6 November 2017

Published online: 28 November 2017

\section{Notes}

1 This is, of course, a simplification for the purpose of framing the conversation. I purposely ignore some of the more interesting questions about impact, such as how academics' different attitudes and approaches toward broader societal impacts might affect evaluations of impact (Samuel and Derrick, 2015); or whether different academic disciplines approach impact differently (Hicks and Holbrook, 2017); or what sort of emotional impact the impact agenda might have on academics (Chubb et al., 2017); or how different policy makers or other members of society might view impact differently.

2 Recent examples in the US include Congressman Lamar Smith (Smith 2016) and Senator Rand Paul (Mervis 2017). See Hill (2016) for a view from the UK.

3 Moriarty (2013) is a salient example.

4 Pudney (2013) makes the case in favor of impact.

5 The term "neopopulism"-much like "neoliberalism"-resists strict definition. I am using it as a generic label to capture what I take to be a shift away from neoliberalism, with the direction toward which we are moving still very much in doubt. Both the election of Donald Trump in the US and the Brexit vote in the UK qualify as "neopopulist" in the sense in which I am using the term here. It also seems that France, Turkey, and others in Europe are trending toward their own versions of neopopulism. There is a family resemblance among all these moves, even if there is no set of necessary and sufficient conditions to provide a definition.

6 I realize that the discussion of promotion and tenure criteria is US-specific. It would be interesting to pursue the question of whether my argument regarding academic freedom also applies in the UK, where academics face a different set of incentives.

7 Thanks to Steve Fuller for introducing me to Berlin's essay. For a discussion of how academic freedom, tenure, and peer review relate to the issue of libraries as scholarly publishers, see Holbrook 2015, from which portions of this and the sections 3 and 4 have been adapted. 
8 In what follows, I focus on academic freedom in the US. For a detailed treatment of academic freedom in the UK as compared to academic freedom across the EU, see Karran (2016).

9 Of course, funding agencies, such as the NSF, are still interested to see that the research they fund has broader impacts. An academic can therefore justify a limited amount of activity aimed at achieving impact as a means to secure grant funding. In terms of tenure and promotion, grants, like publications, are rewarded; broader impacts activities, like teaching, are undervalued.

\section{References}

Academics Anonymous (2016) I couldn't get funding for my research so I "sold out"-and I don't regret it. The Guardian Higher Education Network, 28 October. https://www.theguardian.com/higher-education-network/2016/ oct/28/i-couldnt-get-funding-for-my-research-so-i-sold-out-and-i-dontregret-it

Adorney J (2017) How tuition-free college education hurts young people. National Review, 21 April. http://www.nationalreview.com/article/446924/berniesanders-elizabeth-warren-tuition-free-college-proposal-hurt-students

American Association of University Professors' (AAUP) (1940) Statement of principles on academic freedom and tenure. http://www.aaup.org/report/ 1940-statement-principles-academic-freedom-and-tenure. Accessed 17 April 2017

Allen A (2014) Who benefits from the impact agenda? Times Higher Education, 6 November. https://www.timeshighereducation.com/comment/opinion/whobenefits-from-the-impact-agenda/2016732.article

Berlin I (1958) Two concepts of liberty. Paper presented at the University of Oxford, 31 October

Biagioli M (2002) From book censorship to academic peer review. Emergences 12 (1):11-45

Blake A (2017) Stephen Bannon's nationalist call to arms, annotated. The Washington Post, 23 February. https://www.washingtonpost.com/news/thefix/wp/2017/02/23/stephen-bannons-nationalist-call-to-arms-annotated/? tid=a inl\&utm term $=$. c113eflc0634

Bornmann L (2013) What is societal impact of research and how can it be assessed? A literature survey. J Assoc Info Sci Technol 64(2):217-233

Braben D, Allen J, Amos W (2009) Only scholarly freedom delivers real "impact". The Times Higher Education. https://www.timeshighereducation.com/ comment/letters/only-scholarly-freedom-delivers-real-impact-1/408984. article? storycode $=408984$

Chatham House (2017) Michael Gove on the trouble with experts. https://www. chathamhouse.org/expert/comment/michael-gove-trouble-experts\#sthash. dQRHBQ8K.dpuf. Accessed 24 April 2017

Chubb J (2017) Academics fear the value of knowledge for its own sake is diminishing. The Conversation. https://theconversation.com/academics-fearthe-value-of-knowledge-for-its-own-sake-is-diminishing-75341

Chubb J, Watermeyer R (2016) Artifice or integrity in the marketization of research impact? Investigating the moral economy of (pathways to) impact statements within research funding proposals in the UK and Australia. Stud High Educ 42(12):1-13

Chubb J, Watermeyer R, Wakeling P (2017) Fear and loathing in the academy? The role of emotion in response to an impact agenda in the UK and Australia. High Educ Res Dev 36(3):555-568

Derrick, G, Samuel, G (2017) The future of societal impact assessment using peer review: Pre-evaluation training, consensus building and inter-reviewer reliability. Palgrave Communications, 3 June. http://dx.doi.org/10.1057/ palcomms.2017.40

Donovan C (2008) The australian research quality framework: a live experiment in capturing the social, economic, environmental, and cultural returns of publicly funded research. New Direct Eval 2008(118):47-60

Douglas H (2014) Pure science and the problem of progress. Stud History Philos Sci A 46:55-63

Foucault M (2008) The birth of biopolitics: Lectures at the Collège de France. Palgrave Macmillan, New York, 1978-1979

Frodeman R (2017) The impact agenda and the search for a good life. Palgrave Communications, 9 February. http://doi.org/10.1057/palcomms.2017.3

Frodeman R, Holbrook JB (2012) The promise and perils of transformative research. UNT Digital Library, 2012. http://digital.library.unt.edu/ark:/67531/ metadc84363/. Accessed 17 April 2017

Fish S (2014) Versions of academic freedom: From professionalism to revolution. University of Chicago Press, Chicago

Fuller S (1999) Governance of science: Ideology and the future of the open society. McGraw-Hill International. Buckingham and Philadelphia

Fuller S (2000) Thomas Kuhn: A philosophical history for our times. University of Chicago Press, Chicago

Harley D (2013) Scholarly communication: Cultural contexts, evolving models. Science 4:80-82

Hicks, D, Holbrook JB (2017) The impact of philosophy: Evidence from the UK research excellence framework. http://works.bepress.com/diana_hicks/48/
Hill S (2016) Assessing (for) impact: Future assessment of the societal impact of research. Palgrave Communications, 18 October. https://doi.org/10.1057/ palcomms.2016.73.

Holbrook JB (2010) The use of societal impacts considerations in grant proposal peer review: A comparison of five models. Technol Innov 12(3):213-224

Holbrook JB (2012) Re-assessing the science-society relation: The case of the US National Science Foundation's broader impacts merit review criterion (1997 -2011). In: Frodeman R, Holbrook JB, Mitcham C, Xiaonan H (eds) Peer review, research integrity, and the governance of science-practice, theory, and current discussions. Beijing: People's Publishing House: pp 328-362

Holbrook JB (2015) We scholars: How libraries could help us with scholarly publishing, if only we'd let them. In: Bonn M, Furlough M (eds) Getting the word out: Academic Libraries as Scholarly Publishers, ACRL, pp 43-54

Holbrook JB (2016) Peer review, interdisciplinarity, and serendipity. In: Frodeman R, Klein JT, Pacheco RCS (eds) The oxford handbook of interdisciplinarity, 2nd edn. Oxford University Press, Oxford, p 485-497

Holbrook JB, Kelli RB, Brown KW (2013) Research impact: We need negative metrics too. Nature 7450:439-439

Holbrook JB, Frodeman R (2011) Peer review and the ex ante assessment of societal impacts. Res Eval 20(3):239-246

Karran TJ (2016) Protection for academic freedom in the U.K.: The constitutional and legal situation in a comparative context. http://eprints.lincoln.ac.uk/ 25299/

Langfeldt L, Scordato L (2015) Assessing the broader impacts of research: A review of methods and practices. http://hdl.handle.net/11250/282742

Levine PB (2017) Only a misunderstanding of what college really costs could have produced New York's flawed plan for free tuition. Slate, 26 April. http://www slate.com/blogs/moneybox/2017/04/26/under_new_york_s_flawed_free_ tuition_plan_for_state_schools_some_private.html

Martin BR (2011) The research excellence framework and the "impact agenda": Are we creating a Frankenstein monster? Res Eval 20(3):247-254, https://doi.org/ $10.3152 / 095820211 X 13118583635693$

Mervis J (2017) Rand Paul takes a poke at U.S. peer-review panels. Sciencemag.org. https://doi.org/10.1126/science.aar2630

Miller CA (2017) It's not a war on science. Issue Sci Technol 33(3), http://issues org/33-3/perspective-its-not-a-war-on-science/

Moriarty P (2013) Chasing the money in science funding will lead to fool's gold. The Conversation. https://theconversation.com/chasing-the-money-in-sciencefunding-will-lead-to-fools-gold-14310

National Research Council (2012) For attribution-developing data attribution and citation practices and standards: summary of an international workshop. The National Academies Press, Washington, DC

Newfield C (2017) University research and the great mistake. Inside Higher Ed, 13 April. https://www.insidehighered.com/views/2017/04/13/how-universitieshave-gotten-caught-privatization-trap-essay

NSB/MR-11-22 (2011) National Science Foundation's merit review criteria: Review and revisions, 14 December. https://www.nsf.gov/nsb/publications/2011/ meritreviewcriteria.pdf

Pudney C (2013) Scientists need to prove their research is worth it. The Conversation. https://theconversation.com/scientists-need-to-prove-their-researchis-worth-it-14618

Revkin A (2017) There are lots of climate uncertainties. Let's acknowledge and plan for them with honesty. Pro Publica, 2 May. https://www.propublica.org/ article/climate-change-uncertainties-bret-stephens-column

Rip A (2000) Higher forms of nonsense. Eur Rev 8(4):467-485

Romm J (2017) The NY Times promised to fact check their new climate denier columnist-they lied. Think Progress, 29 April. https://thinkprogress.org/theny-times-promised-to-fact-check-their-new-climate-denier-columnist-theylied-72ad9bdf6019

Samuel GN, Derrick GE (2015) Societal impact evaluation: Exploring evaluator perceptions of the characterization of impact under the REF2014. Res Eval 24 (3):229-241

Science News Staff (2017) How science fares in the US budget deal. ScienceInsider, 1 May. http://www.sciencemag.org/news/2017/05/how-science-fares-usbudget-deal

Smith L (2016) Fact check: Scientific research in the national interest act. Issue Sci Technol 32(2) (Winter) http://issues.org/32-2/fact-check-scientificresearchin-the-national-interest-act/

Stephens B (2017) Climate of complete certainty. New York Times, 28 April. https:/www.nytimes.com/2017/04/28/opinion/climate-of-completecertainty.html

Stover D (2017) Experts respond to Trump's climate blitzkrieg. Bulletin of the Atomic Scientists 29 March. http://thebulletin.org/experts-respond-trump\% E2\%80\%99s-climate-blitzkrieg10648?platform=hootsuite

\section{Data availability}

Data sharing is not applicable to this paper as no datasets were generated or analysed. 


\section{Acknowledgements}

This material is based upon work supported by the National Science Foundation under Grant No 1445121. Any opinions, findings, and conclusions or recommendations expressed in this material are those of the author and do not necessarily reflect the views of the National Science Foundation.

\section{Additional information}

Competing interests: The author declares no competing financial interests.

Reprints and permission information is available online at http://www.nature.com/ reprints

Publisher's Note: Springer Nature remains neutral with regard to jurisdictional claims in published maps and institutional affiliations. (c) Open Access This article is licensed under a Creative Commons Attribution 4.0 International License, which permits use, sharing, adaptation, distribution and reproduction in any medium or format, as long as you give appropriate credit to the original author(s) and the source, provide a link to the Creative Commons license, and indicate if changes were made. The images or other third party material in this article are included in the article's Creative Commons license, unless indicated otherwise in a credit line to the material. If material is not included in the article's Creative Commons license and your intended use is not permitted by statutory regulation or exceeds the permitted use, you will need to obtain permission directly from the copyright holder. To view a copy of this license, visit http://creativecommons.org/ licenses/by/4.0/.

(C) The Author(s) 2017 